\title{
Retrospective evaluation of postsurgical outcomes of patients operated with the diagnosis of pulmonary hydatid cyst
}

\section{Akciğer kist hidatik tanısı ille opere edilen hastaların cerrahi sonuçlarının retrospektif analizi}

İlbrahim Ethem Özsoy, Mehmet Akif Tezcan, Fatih Güirler, Ahmet Oral

Department of Thoracic Surgery, Kayseri Health Practice and Research Center, University of Health Sciences, Kayseri, Turkey Corresponding author: İbrahim Ethem Özsoy, MD, Department of Thoracic Surgery, Kayseri Health Practice and Research Center, University of Health Sciences, Kayseri, Turkey

E-mail: ieozsoy@gmail.com

Received/Accepted: May 22, 2020 /July 14, 2020

Conflict of interest: There is not a conflict of interest.

\section{SUMMARY}

Objective: Hydatid cysts may occur in almost every organ and tissue of human the body. Because they can be found in more than one organ/tissue, sometimes many operations may need for them and surgical intervention may be required due to complications that may develop secondary to hydatid cyst surgery albeit few.

Method: Data on patient files retrieved from the hospital information management system or archive were analyzed retrospectively. Surgical results of patients operated with the diagnosis of hydatid cyst between 2008 and 2018 in our clinic were discussed retrospectively.

Results: Ninety-three operations were performed in 84 patients due to pulmonary hydatid cysts. Fourty-four of them were male (52.4\%), 40 were female and their mean age was $44(5-85)$ years. Twenty-two $(26.2 \%)$ patients were asymptomatic and $62(73.8 \%)$ were symptomatic. Hydatid cysts were located in right hemithorax in $45(53.6 \%)$ patients, in left hemithorax in $30(35.7 \%)$ patients and bilaterally in $9(10.7 \%)$ patients. Twenty-six patients $(31 \%)$ had both pulmonary and hepatic hydatid cysts. Posterolateral thoracotomy and cystotomy-capitonnage were the most common methods $(89.3 \%), 9$ patients $(10.7 \%)$ underwent wedge resection. Four patients developed atelectasis, 2 patients had hydropneumothorax, 4 patients had isolated prolonged air leak, 1 patient developed massive pulmonary embolism, and 1 patient developed Aspergillus infection the quilted cavity.

Conclusions: Hydatid cyst disease has still been a serious health concern in Turkey. When the careful and experienced surgeons perform the operations, the postoperative period is usually uneventful and morbidity is extremely low.

Keywords: Hydatid cyst, morbidity, cystotomy, capitonnage.
(D) İbrahim Ethem Özsoy
(iD) Mehmet Akif Tezcan
(D) Fatih Gürler
(D) Ahmet Oral

ORCID IDs of the authors:

İ.E.Ö. 0000-0003-2722-5309

M.A.T. 0000-0002-2642-187X

F.G. 0000-0001-9745-4209

A.O. 0000-0002-8623-3918

\section{ÖZET}

Amaç: Hidatik kist hemen her organ ve dokuya yerleşebilir. Birden fazla organ/dokuya yerleşebildiğinden, bazen çok sayıda ameliyat gerekebilmekte ve az sayıda da olsa hidatik kist ameliyatına bağlı gelişebilen komplikasyonlar nedeniyle tekrar cerrahi girișim gerekebilmektedir. 
Yöntem: Hastane bilgi yönetim sisteminden veya arşivden hasta dosyaları alınarak verilere ulaşıldı. Kliniğimizde 20082018 yılları arasında kist hidatik tanısı ile ameliyat edilen hastaların cerrahi sonuçları retrospektif olarak tartıșıldı. Bulgular: Akciğer kist hidatik nedeniyle 84 hastaya 93 operasyon yapıldı. Olguların 44'ü erkek (\%52.4), 40'^ kadındı (\%47.6) ve yaş ortalaması 44 (5-85) y1l idi. Hastaların 22'si (\%26.2) asemptomatik, 62'si (\%73.8) ise semptomatikti. Hidatik kistler 45 (\%53.6) olguda sağ hemitoraks, 30 (\%35.7) olguda sol hemitoraks, 9 (\%10.7) olguda bilateral yerleşimliydi. Yirmi altı hastada (\%31) akciğer ve karaciğer hidatik kist birlikteliği mevcuttu. Posterolateral torakotomi ile kistotomi-kapitonaj yöntemi en sik uygulanan yöntemdi (\%89.3), dokuz olguya ise wedge rezeksiyon (\%10.7) uygulandı. Dört olguda atelektazi, 2 olguda hidropnömotoraks, 4 olguda izole uzamış hava kaçağı, 1 olguda massif pulmoner emboli ve 1 olguda da kapitone edilen boşlukta Aspergillus enfeksiyonu gelişti.

Sonuç: Hidatik kist hastalığı ülkemizde hala önemli bir halk sağlı̆̆ı sorunu olarak devam etmektedir. Dikkatli ve tecrübeli ellerin yaptığı cerrahi sonrası genellikle sorunsuz seyreder ve morbiditesi son derece düşüktür.

Anahtar sözcükler: Hidatik kist, morbidite, kistotomi, kapitonaj.

\section{INTRODUCTION}

Hydatid cysts may occur in almost every organ and tissue of human the body. Since they are located especially in the liver or in the lungs together with it, every pulmonologist has more or less experienced or struggled with this disease. Just as we may encounter very interesting clinical pictures of diagnosis, the physicians who handle the surgical aspect of the treatment may face very distressing and rare conditions although their surgery may seem easy. Diagnosis cannot always be made before surgery and, sometimes, it can be made during surgery. Because they can be found in more than one organ/tissue, sometimes many operations may need for them and surgical intervention may be required due to complications that may develop secondary to hydatid cyst surgery albeit few ${ }^{1}$.

The most effective treatment of a pulmonary hydatid cyst is the complete excision of the cyst according to the principles that will maximally protect the lung parenchyma by avoiding resections as much as possible. The aim of surgical treatment is to completely eliminate the parasite, to prevent the spread that may occur with intraoperative rupture of the cyst and to remove the remaining cavity arising from the surgical procedures ${ }^{2}$.

Postoperative morbidity has been adversely affected by the number, size, and type of operation of the hydatid cysts. The complication rate in the various series ranges between $3.5 \%$ and $7.5 \%$. The most common postoperative complications include prolonged air leak, atelectasis, and empyema ${ }^{3,4}$.

\section{MATERIAL AND METHODS}

This study was approved by the local ethics committee. The study was conducted in accordance with the principles of the Declaration of Helsinki.

Ninety-three operations were performed in 84 patients due to pulmonary hydatid cysts in Health Application and Research Center between 2008 and 2018. Data on patient files retrieved from the hospital information management system or archive were analyzed retrospectively. Pulmonary hydatid cyst was diagnosed with the patient's history and/or posteroanterior chest radiography and computerized thorax tomography. Postoperative morbidity was assessed in terms of age, gender, cyst diameter, cyst localization, number of cysts, presence of complications, the involvement of other organs. Hematological and biochemical parameters of all patients were evaluated.

Statistical analyses were performed using SPSS software for Windows version 22.0. The numerical values were expressed as mean \pm standard deviation (mean $\pm \mathrm{ss}$ ) and categorical values were expressed as median \pm minimum maximum (median \pm min-max). The suitability of the parameters to normal distribution was evaluated by Kolmogorov-Smirnov test. In comparison of quantitative data, One way Anova test was used for comparing parameters showing normal distribution, and Mann-Whitney U-test was used for comparison of parameters not showing normal distribution. Chi-square test was used for the comparison of quantitative data. $\mathrm{P}<0.05$ was condidered to indicate statistical significance.

\section{RESULTS}

Eighty-four patients operated for hydatid cysts were included in this study. Fourty-four of them were male $(52.4 \%), 40$ were female and their mean age was $44(5-85)$ years. Twenty-two (26.2\%) patients were asymptomatic and $62(73.8 \%)$ were symptomatic. The most common symptoms were chest pain, cough, purulent sputum, and hemoptysis. Asymptomatic patients had cystic lesions on chest radiographs taken for any reason and they were referred to us. They usually had small intra-parenchymal cysts. Sixty- two (73.8\%) of patients had noncomplicated hydatid cysts, 22 (26.2\%) of them suffered from complicated hydatid cysts. Hydatid cysts were located in right 
hemithorax in $45(53.6 \%)$ patients, in left hemithorax in $30(35.7 \%)$ patients and bilaterally in $9(10.7 \%)$ patients. In noncomplicated bilateral hydatid cyst cases, the side with larger or more cysts was operated first. Five of the bilateral hydatid cysts were complicated. Abdominal ultrasonography was carried out in all patients. The suspected situation in the ultrasound examination was supported by abdominal tomography. Twentysix patients $(31 \%)$ had both pulmonary and hepatic hydatid cysts (Figure 1). The mean cyst diameter was $6.1 \mathrm{~cm}(1-11 \mathrm{~cm})$, and the cyst diameter was over $10 \mathrm{~cm}$ in 8 patients $(9.5 \%$ ) (Figure 2). Posterolateral thoracotomy was performed in all patients. Two-stage thoracotomy was performed for bilaterally patients. The time between two thoracotomies was at least one month. Cystotomycapitonnage were the most common methods $(89.3 \%)$ (Figure 3). Wedge resection was performed for nine small cysts (10.7\%) with peripheral localization. Demographic data, cyst characteristics, and surgical procedures are presented in Table 1. Twelve (12.9\%) of the operated patients developed a postoperative surgical complication (Table 2).

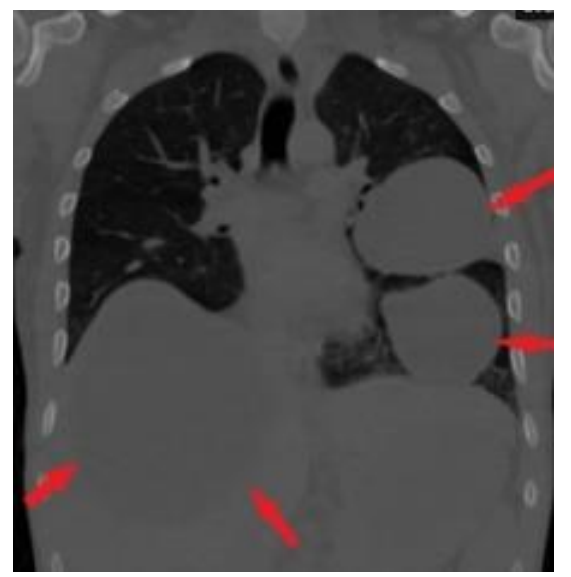

Figure 1. Coexistence of lung and liver hydatid

cyst in thorax tomography

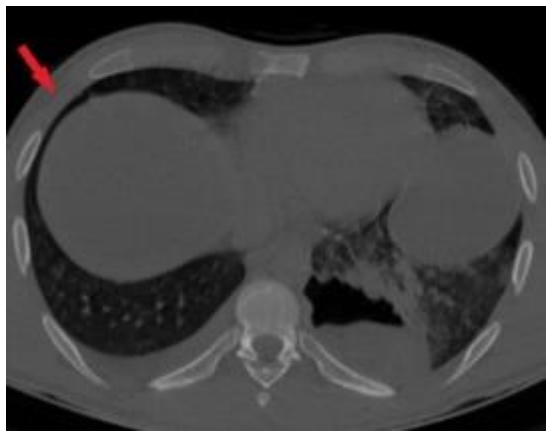

Figure 2. Giant hydatid cyst in right side

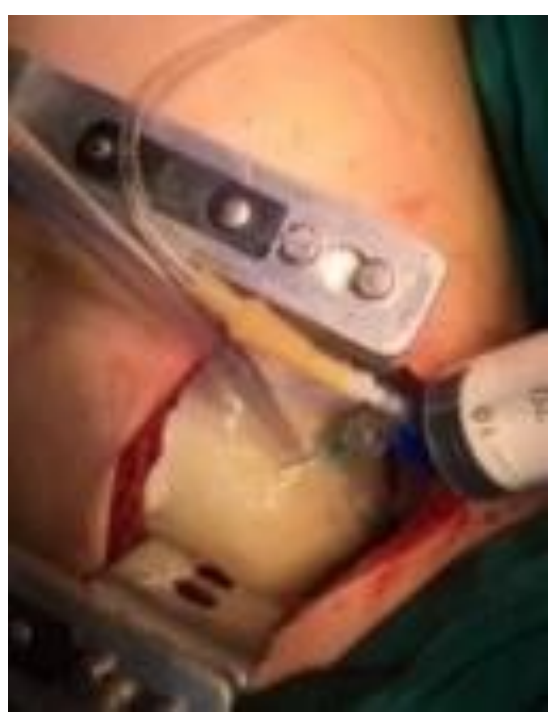

Figure 3. Lung hydatid cyst at posterolateral thoracotomy

Table 2: Cyst localization and postoperative morbidity

\begin{tabular}{|l|c|c|c|}
\hline Morbidity & $\begin{array}{c}\text { Unilateral } \\
\text { (Singular) }\end{array}$ & $\begin{array}{c}\text { Unilateral } \\
\text { (Multiple) }\end{array}$ & $\begin{array}{c}\text { Bilateral } \\
\text { (Multiple) }\end{array}$ \\
\hline Atelectasis & 1 & 2 & 1 \\
\hline Hydropneumothorax & 1 & 1 & 0 \\
\hline Prolonged air leak & 1 & 2 & 1 \\
\hline Massive thromboembolism & 1 & 0 & 0 \\
\hline Intracavitary aspergilloma & 1 & 0 & 0 \\
\hline
\end{tabular}


Table 1: Demographic data, cyst character, and used methods of surgery

\begin{tabular}{|l|c|}
\hline Data & $\mathbf{n}(\boldsymbol{\%})$ \\
\hline Mean age (years) & $\mathbf{4 4 ( 5 - 8 5 )}$ \\
\hline Gender & $40(47.6 \%)$ \\
Female & $44(52.4 \%)$ \\
Male & $\mathbf{6 . 1 ( 1 - 1 1 )}$ \\
\hline Cyst size (cm) & $30(35.7 \%)$ \\
\hline Cyst localization & $45(53.6 \%)$ \\
Left & $9(10.7 \%)$ \\
Right & $18(21.4 \%)$ \\
Bilateral & $66(78.6 \%)$ \\
\hline Cyst number & $\mathbf{2 6 ( 3 1 \% )}$ \\
Multiple & \\
Singular & $75(89.3 \%)$ \\
\hline Cysts in other organs & $66(78.6 \%)$ \\
\hline Methods of surgery & $9(10.7 \%)$ \\
One- stage thoracotomy & $9(10.7 \%)$ \\
Cystotomy-capitonnage & $\mathbf{9 . 3}$ \\
Wedge resection & \\
Two stage bilateral thoracotomy & \\
\hline Hospital stay (days) &
\end{tabular}

Four patients developed atelectasis (2 with unilateral multiple cysts and 2 with unilateral giant cysts), 2 patients had hydropneumothorax (both patients with unilateral cysts 4 and over), 4 patients had isolated prolonged air leak ( 2 with a single simple cyst and 2 with unilateral multiple cysts), 1 patient (56-year-old female with unilateral 4-cm simple cyst) developed massive pulmonary embolism at the first postoperative hour, and 1 patient (48-year-old male with ruptured cyst) developed Aspergillus infection the quilted cavity one month later and wedge resection was performed for this re-operated patient. The relationship between the development of complications in the postoperative period with the unilateral single, unilateral multiple or bilateral formation of the cyst was found statistically insignificant $(\mathrm{P}=0.68)$. Mean length of stay in the hospital was 9.3 days.

\section{DISCUSSION}

Hydatid cyst has been known since ancient times. Hippocrates (460-377 BC) reported the presence of hydatid cysts in cattle and pigs and described it as a "water-filled sac (Jecur aqua repletum)". It is known that in Aristotle's (384-322 BC) manuscript, this water sac damaged the liver and lung ${ }^{5}$. It is common all over the world. High prevalence of parasites has been reported from Eurasia (Mediterranean countries, Russian Federation and Turkish Republics), North Africa,
Australia and South America ${ }^{6}$. Although it is seen in every region of Turkey, it is more often seen in Central Anatolia, Marmara and Thrace regions, notably in the Eastern Anatolia region ${ }^{7}$.

Although hydatid cysts are present in every lobe of the lung, they are more common in the right hemithorax and lower lobes. The literature review shows that the rate of pulmonary cysts in the right hemithorax ranged from $52.7 \%$ to $63.2 \%$. Bilateral lung presence of hydatid cysts ranged between $2 \%$ and $14.8 \%{ }^{8,9}$. Liver involvement occurred between $6 \%$ and $25 \%$ in the series of patients with pulmonary hydatidosis ${ }^{9}$. We found that $45(53.6 \%)$ of the lung cysts were located in the right lung and $30(35.7 \%)$ in the left lung. In our study, 9 patients $(10.7 \%)$ had bilateral pulmonary involvement, and $26(31 \%)$ patients had coexisting lung and liver hydatid cysts.

The primary surgical treatment of a lung hydatid cyst is based on the principle that as much lung tissue as possible is preserved during surgery. Intact cysts should be operated immediately due to the risk of infection and rupture. Even if the intracystic parasite is dead, the remaining germinative membrane should be removed by the operation as it may be the source of infection. Today, the aim of surgical treatment is to remove the cyst and germinative membrane and avoid contamination while doing so. Parenchymal protective surgical methods (enucleation, 
cystotomy-capitonnage, pericystotomy, and limited wedge resection) are used in hydatid cyst surgery. The resective surgery may be feasible if more than $50 \%$ of the lobe is devastated ${ }^{4,9,10}$. Nowadays, endoscopic and minimally invasive procedures become popularized. Whereas the thoracotomy is the standard current practice in pulmonary hydatid cyst, Turkey pioneers the world in video-assisted thoracoscopic surgery (VATS) applications, the studies reporting that cysts in selected cases would successfully be removed are also submitted from our country ${ }^{11,12}$. We should keep in mind that each case may differ from each other and, therefore, we should adopt a casespecific approach. We applied parenchymal protective surgery to our patients as much as possible. Cystotomy-capitonnage was the most common surgical procedure, with $89.3 \%$. Limited wedge resection from segmentectomy was performed in the ratio of $10.7 \%$. We needed radical resection for none of our patients. Our next objective is to perform VATS in single and peripheral lesions and to use a minimally invasive method in hydatid cyst for our patients.

The postoperative morbidity rate ranges from 3.5 to $20 \%$ in various series. The morbidity is affected by the number and size of hydatid cysts, and type of operation. It is reported that ruptured hydatid cysts lead to higher morbidity than intact cysts. Postoperative atelectasis, prolonged air leak, and empyema are the most common complications. In addition, major complications such as wound site infection, residual cavity development, and thrombophlebitis may occur. Almost all of these complications are minor ones that are ameliorated by conservative methods 4,9,10,13. Sometimes, although rare, there are cases reporting that have developed opportunistic infections such as aspergilloma ${ }^{14}$. Twelve $(12.9 \%)$ of our patients developed the postoperative surgical complications. Atelectasis, hydropneumothorax, isolated prolonged air leak, massive pulmonary embolism and Aspergillus infection developed in 4 patients, 2 patients, 4 patients, 1 patient at the postoperative first hour and in the quilted cavity in 1 patient, respectively. The patient developing Aspergillus infection was operated again. Of the patients developing Atelectasis, 2 had unilateral multiple cysts and 2 had giant hydatid cysts greater than $10 \mathrm{~cm}$. Hydropneumothorax developed in 2 patients 7 and 10 days after being discharged and tube thoracostomy was sufficient for them. There was no massive leak in patients with prolonged air leak, and their tube thoracotomies were discontinued with the blood patch.
Cysts with a diameter greater than $10 \mathrm{~cm}$ in any axis are generally described as "Giant Hydatid Cysts. Applying surgical procedures is more difficult in giant cysts than in small ones, and morbidity is more common in the postoperative period. There are 5\% higher morbidity rates in giant hydatid cysts than in the others. Önen et al. ${ }^{15}$ reported that $15.4 \%$ of the patients operated had giant cysts and $30 \%$ of them developed postoperative morbidity. Meteroglu et al. ${ }^{16}$ found that, in their study, 67 (35.1\%) of 191 hydatid cysts being operated in 11 years were giant and this rate reached $34.9 \%$ in giant hydatid cysts despite $31.4 \%$ of postoperative morbidity in all patients with cysts. Çobanoglu et al ${ }^{17}$ reported that giant hydatid cyst rates were $15.3 \%$ and their morbidity had $12.5 \%$. The number of giant hydatid cysts in patients we operated was $8(9.5 \%)$ and 2 of them (25\%) developed postoperative complications. Considering all the patients with hydatid cysts we operated, we found almost twice as high as the percentage reported ( $25 \%$ vs $12.9 \%$ ).

\section{CONCLUSION}

Hydatid cyst disease has still been a serious health concern in Turkey. When the careful and experienced surgeons perform the operations, the postoperative period is usually uneventful and morbidity is extremely low.

\section{Acknowledgments}

Consent: Written informed consent was obtained from all participants as well as from the local Ethics Commitee. (Date: 23.10.2019/579)

Conflict of Interest: No conflict of interest was declared by the authors.

Financial Disclosure: This was not an industry supported study. The authors declare that this study has received no financial support.

All authors contributed to the design and implementation of the research, to the analysis of the results and to the writing of the manuscript. All authors discussed the results and contributed to the final manuscript.

Presentation at a meeting: Oral presentasion, RESPIRATION 2019, Bodrum, 26-29 October 2019

\section{REFERENCES}

1. Oruç M, Şahin A, Meteroğlu F, et al. Comparison of Demographical Characteristics, Prognostic Factors, and Surgical Outcomes in Children and Adult Patients with Pulmonary Hydatid Cyst. Eurasian Journal of Pulmonology 2017;19;(3):166-169.

2. Üçvet A, Gürsoy S. Cerrahi yaklaşım. In: Yalçınkaya İ. (ed.), Akciğer Hidatik Kisti. 
Ankara, Türkiye Solunum Araştırmaları Derneği, 2016:51-67.

3. Durkan A, Özturk B, Çakmak M. Analysis of pulmonary hydatid cysts underwent surgery. Biomedical Research 2018; 29 (9): 1865-70.

4. Ozyurtkan MO, Balci AE. Surgical treatment of intrathoracic hydatid disease: a 5-year experience in an endemic region. Surg Today. 2010;40(1):31-7.

5. McManus DP, Zhang $\mathrm{W}, \mathrm{Li} \mathrm{J}$, et al. Echinococcosis. The Lancet. 2003; 362:1295304.

6. Eckert J, Deplazes P. Biological, Epidemiological, and Clinical Aspects of Echinococcosis, a Zoonosis of Increasing Concern. Clinical Microbiology Reviews 2004; 17:107-35.

7. Altintas N. Past to present: Echinococcosis in Turkey. Acta Tropica 2003; 85:105-12.

8. Dogusoy I. Management of hydatid cysts. In: Franco KL,Putnam J, editors. Advanced therapy of thoracic surgery. 2nd ed. New York: BC Decker Inc; 2005. p. 241-50.

9. Işıtmangil T, Görür R, Yiyit N, et al. Evaluation of 308 patients surgically treated for thoracic hydatidosis. Türk Göğüs Kalp Damar Cer Derg 2010;18(1):27-33
10. Sivrikoz MC, Boztepe H, Döner E, et al. Hydatid Cyst of Lung and Surgical Therapy. Solunum 2011; 13(3): 166-169.

11. Eroglu A, Aydin Y, Altuntas B. Video-assisted thoracoscopic surgery is safe and effective in the treatment of pulmonary hydatid cyst. Ann Thorac Surg. 2016; 101(2):829.

12. Alpay L, Lacin T, Atinkaya C, et al. Videoassisted thoracoscopic removal of pulmonary hydatid cysts. Eur J Cardiothorac Surg. 2012;42(6):971-5.

13. Balcı AE, Eren N, Eren Ş, Ülkü R, Cebeci E. Akciğer kist hidatiği: 728 olgunun cerrahi tedavi ve izlemi. Solunum Hastalıkları 2001;12:216-21.

14. Kıral H, Yalçınkaya İ, Küpeli M, Demirhan R. Intracavitary aspergilloma after hydatid cyst surgery:a case report. Türk Göğüs Kalp Damar Cerrahisi Dergisi 2012;20(2):381-383.

15. Önen A, Şanlı A, Avcı BY. Akciğerin Dev Kist Hidatiği: 10 Olgu Sunumu. Toraks Dergisi 2004;5(2):106-9.

16. Meteroglu F, Sahin A, Eren S, et al. Giant hydatid cysts of the lung: Analysis and surgical outcome of 67 cases. Ann Trop Med Public Health 2013;6:188-189.

17. Çobanoğlu U, Yalçınkaya İ. Akciğerin dev hidatik kisti: 24 olgunun analizi. Solunum 2008;10:119-125. 